\title{
The Effect of the Global Financial Crisis on Earnings Management and Executive Compensations: UK Evidence
}

\author{
Dr Ahmed Hassan Ahmed \\ Lecturer in Accounting \\ Faculty of Commerce, \\ South Valley University
}

\begin{abstract}
The research questions of the present paper have been motivated by the Global Financial Crisis (GFC) that hit almost the whole globe in 2007-2008. The purpose of the current study is to examine the effect of the global financial crisis on the level and direction of earnings management during crisis period as well as the effect of this crisis on the level and structure of executive compensation during the same period using a sample of the UK FTSE 350 nonfinancial companies. Regarding the effect of global financial crisis on earnings management practices; the results showed that firms engaged in higher levels of earnings management. More specifically, the findings revealed that firms managed earnings downward during the crisis period. These results are consistent with the argument that firms may have recourse to income decreasing earnings management during crisis periods to gain governmental aid, relax debt covenant and lower interest rates. With regard to the impact of the GFC on executive compensation, the results indicated that the sample firms provided less total compensations during the crisis period; however firms offer higher salaries, bonus, and direct compensations. Surprisingly, the results show that CEO's ownership increased during the crisis period, implying that they could not anticipate the financial crisis. Moreover, the study reported that the quality of corporate governance system of the sample companies does not have a significant effect on earnings management practices or on the level and structure of executive compensations during the crisis period.
\end{abstract}

To the best of the author's knowledge, this paper is one of the first papers that examine the impact of the GFC on earnings management and executive compensations using UK data, as most 
of the extant literature have been undertaken in the US. Although both countries represent the Anglo-American model of corporate governance, the UK has a different institutional environment regarding many aspects of executive compensation. Therefore, the results of US studies cannot be generalised to the UK. The current paper also provides up-to-date evidence regarding the implications of the GFC on earnings management and executive compensations. The results presented in the current study provide more understanding of the consequences of financial crises on earnings management and executive compensations, especially with the absence of any consensus in this regard.

Keywords: Financial Crisis; Earnings Management; Corporate Governance; Executive Compensation; UK.

\section{Introduction}

Jensen and Meckling (1976) posit that agency problem arises fundamentally because of conflict of interests between shareholders and managers. Shareholders want managers to increase the value of the firm, but managers may act to promote their self-interests at the expense of the firm, for example, by adopting financing policies and a capital structure for the firm which can help to secure their job. In other words, managers could engage in earnings management practices as a way to maximise their benefits. In this vein, Healy and Wahlen (1999, p. 368) asserted that:

"Earnings management occurs when managers use judgment in financial reporting and in structuring transactions to alter financial reports to either mislead some stakeholders about the underlying economic performance of the company or to influence contractual outcomes that depend on reported accounting numbers"

To alleviate the agency problems and in a way that could align the interests of both the principal and agent, the agency theory suggest that executive pay is a "device" with which could be used to reconcile the interests of executives with that of shareholders. The Asian Financial Crisis in 1997, corporate scandals in the US and Europe leading to the failure and collapse of large corporations such as Enron, WorldCom and Parmalat and the 2007-2008 Global Financial Crisis (GFC) have badly undermined confidence in capital markets and provoked stakeholders to press 
for changes in corporate governance practices (Falgi, 2009). In order to restore confidence in financial reporting there has been a global call for more attention to be devoted to corporate governance matters, and international regulators and standardsetters have issued detailed regulations and codes dealing with these issues (Falgi, 2009). In this context, the basic role of corporate governance mechanisms are to monitor, control, or direct the management to achieve the maximum benefit for all parties of the organization (Shleifer and Vishny, 1997; Denis and McConnell, 2003). In other words, the role of corporate governance is to rectify the bad effects of agency relationships among different stakeholders. It is believed that during crisis periods many companies experience a systematic deterioration to profits, while other companies may report losses (Bepari et al., 2013) which in turn lead to uncertainty about future earnings. This uncertainty could encourage investors to revise their investment decisions. Consequently, management can use accounting choices to manipulate accounting figures by engaging in earnings management practices. Some of the extant literature revealed that companies engage in aggressive earnings management practices throughout crisis periods (Chia et al., 2007). Other studies indicated that management may engage in financial reporting practices to enhance investor confidence in capital markets and provide more enhanced financial reporting quality (Arther et al., 2015). For example, the extant literature reported that in booming periods management would be motivated more to engage in income-increasing earnings management, while in economic downturn periods managers may be more conservative and would report deflated earnings or losses (Strobl, 2013; Kane et al., 2015). In other words, during crisis periods, firms would be exposed to substantial pressure from interested parties which in turn may motivate managers to manage earnings to improve the firm's performance. An alternative perspective suggests that in crunch times investors generally prepared to accept a fall in earnings or losses, therefore management would be less encouraged to manage earnings (Filip and Raffournier, 2014).

As mentioned above, executive compensation would be used to alleviate the agency problems and align the conflicting interests of both the agent and principles. These compensation may consist of different components: base salary, bonus, stock options, restricted 
stock, long-term incentive plans and retirement plans (Murphy, 1985; Chang and Chen, 2011). These compensations could be linked to high risk taking behaviour by managers (Chang and Chen, 2011). The GFC has been partly blamed on remuneration policies employed by different companies worldwide. According to Turner (2009) "there is a strong prima facie case that inappropriate incentive structures played a role in encouraging behaviour which contributed to the financial crisis" (p. 79).

It is believed that the GFC has started in the US market in mid2007 with its impact being felt worldwide in 2008 . Therefore, the time horizon for the present study is 2004-2011, so we would be able to see the situation before during and after the GFC that hit most of the globe in 2008. The GFC was considered to be the worst financial crisis since the Great Depression of the 1930s (Temin, 2010). Even more, Ben Bernanke, former Federal Reserve Chairman, claims that the $\mathbf{2 0 0 8}$ financial crisis was actually worse than 1930s's Great Depression ${ }^{1}$. It has led to economies' recession, companies' downsize or closing, thousands of workers losing their jobs, the UK economy was not different, as there was a large fall in retail sales which in turn led to a decline in profitability. In the $4^{\text {th }}$ quarter of 2008 the UK Gross Domestic Product (GDP) fell by $1.5 \%$ and the country officially entered a period of recession, which continued through 2009 , with signs of recovery became apparent towards the end of that year. Undoubtedly, this crisis affected the firms' financial reporting processes as well as their structure of executive compensation. Therefore, the main purpose of the current paper is to examine the effect of global financial crisis on earnings management practices and executive compensation by UK companies. Talking into consideration the importance of corporate governance mechanisms, the study goes further to examine the impact of CG practices on EM and executive compensation.

Based upon the preceding discussion, the current study embraces two research questions:

1. What is the impact of the GFC on EM practices of UK companies?

2. What is the impact of the GFC on executive compensation of UK companies?

\footnotetext{
${ }^{1}$ Ben Bernanke speech was quoted in Wall Street Journal on 26/8/2014. The article can be retrieved from this site: http://blogs.wsj.com/economics/2014/08/26/2008meltdown-was-worse-than-great-depression-bernanke-says/
} 
The results showed that firms engaged in higher levels of earnings management. In addition, the findings revealed that firms managed earnings downward during the crisis period. These results are consistent with the argument that firms may have recourse to income decreasing earnings management during crisis periods to gain governmental aid, to relax debt covenant and lower interest rates. The results also indicated that the sample firms provided less total compensation during the crisis period; however firms offer higher salaries, bonus, and direct compensation. Surprisingly, the results show that CEO's ownership increased during crisis period, implying that they could not anticipate the financial crisis. Moreover, the study found that quality of corporate governance system of the sample companies does not have a significant effect on earnings management practices or on the level and structure of executive compensation during the crisis period.

To the best of the author's knowledge, this paper is one of the first papers that examine the impact of the GFC on earnings management and executive compensations using UK data, as most of the extant literature have been undertaken in the US. Although both countries represent the Anglo-American model of corporate governance, the UK has a different institutional environment regarding many aspects of executive compensation. Therefore, the results of US studies cannot be generalised to the UK. The current paper also provides up-to-date evidence regarding the implications of the GFC on earnings management and executive compensations. The results presented in the current study provide more understanding of the consequences of financial crises on earnings management and executive compensations, especially with the absence of any consensus in this regard.

The remainder of this paper is structured as follows: The extant literature and hypotheses formulation is discussed in Section 2. Section 3 illustrates the methodology of the current study before Section 4 describes and discusses the empirical evidence, while robustness check is reported in Section 5. Section 6 concludes the paper. 


\section{Literature Review and Hypotheses Formulation}

\subsection{The Impact of Financial Crisis on Earnings Management}

This section investigates the impact of the GFC on firms' earnings management behaviour. While there are some reasons that may motivate managers to manage earnings upward or downward during crisis periods, there are other causes that may restrain firms from managing earnings during these periods. Factors that may induce firms to manage earnings upward include debt covenant. In this context, Dichev and Skinner (2001) argued that earnings are amongst the factors that affect debt covenants. Therefore, firms may resort to income increasing earnings management in order to avoid the probability of violations (DeFond and Jiambalvo, 1994; Sweeney, 1994; Saleh and Ahmed, 2005; Sincerre et al., 2016). Another factor that may push firms towards practising income increasing earnings management is the need to compensate the negative effects of economic downturn on operational performance (Ahmad-Zaluki et al., 2011) or to avoid a significant deterioration of the firm's stock price that would negatively influence management compensations (Charitou et al., 2007). Consistent with the argument that periods of economic turbulence motivate managers to manipulate earnings upward, Ahmad-Zaluki et al. (2011) report that income-increasing earnings management by Malaysian firms engaged in initial public offerings was limited to IPOs that occurred during the Asian crisis period (1997-1998).

On the other side, periods of economic downturn may enforce managers to manipulate earnings downward. In this regard, firms may manage earnings downward to gain governmental aids. It is well known that governments may help troubled firms during economic crisis. Since firms are more likely to get such benefits if they are financially distressed, this may encourage them to deflate earnings. The extant literature provides some evidence which support this argument. For example, DeAngelo et al. (1994) indicated that distressed firms may use their financial troubles to claim for antitrust clearance or import relief. Furthermore, another reason that may push firms towards income-decreasing earnings management is the desire to get some concessions from the lenders through reporting losses. It is known that firms that violate debt covenant or miss debt repayment may be obliged for liquidation. Nevertheless, this may not be beneficial for lenders as 
assets are usually undervalued during recession time (Shleifer and Vishny, 1992). In this case, lending institutions may prefer to restructure debt through relaxing covenant, deferring payments, or cutting interact rate (Asquith and Gertner., 1994).

Contrary to the above argument discussed above which suggested that crisis periods are characterised with high levels of earnings management, there is another stream that argue that periods of economic downturn are less favourable for earnings management practices compared to time of economic stability. One possible explanation for this is that firms are exposed to more monitoring from governmental agencies, auditors, investors and other stakeholders during crisis periods, which may reduce managers' discretion over earnings (Chia et al., 2007). Moreover, periods of crisis are associated with high litigation risk and mangers normally respond to this high litigation risk by decreasing the levels of earnings management and consequently increasing the level of conservative earnings (Jenkins et al., 2009). This argument is also supported by Huijgen and Lubberink (2005) who find that firms in high legal liability regimes report more conservative earnings.

The above discussion might not lead us to clear direction regarding the effect of global the GFC on earnings management, nevertheless, our trend analysis for earnings management behaviour over the sample time (2004-2011) show that years of crisis (especially 2008) showed higher levels of earnings management. Also, the experience from the Asian financial crisis (1997-1998) indicated that firms are more likely to manipulate earnings upwards during periods of crisis. Accordingly, the study argues that the GFC pushed firms to higher levels of income increasing earnings management. Thus, the study propose the following two hypotheses:

Hc1: The GFC was associated with high levels of earnings management

Hc2: The GFC was associated with income- increasing earnings management 


\subsection{The Effect of the Global Financial Crisis on Executive Compensation}

As mentioned above, compensations of banks' executives have got lots of blame as one of the major factors that caused the GFC. In this context, Alan Blinder argues that these incentives are "one of [the] most fundamental causes" of the credit crisis (Wall Street Journal, 2009). In addition, Turner (2009: p.79) mentions that "there is a strong prima facie case that inappropriate incentive structures played a role in encouraging behaviour which contributed to the financial crisis", while, Fahlenbrach and Stulz (2011) find that banks in which incentives for executives are well linked to shareholders' interests performed badly during the GFC.

Instead of investigating the role of executive compensations in creating the global financial crisis, this paper looks to the opposite side of the picture. It examines the effect of this crisis on the level and structure of executive compensation amongst UK listed companies. Executive compensations get more spot from media and the public during periods of economic crisis. Firms may react to the pressures of media and the public by changing the level as well as the structure of their compensation packages. In this regard, Finkelstein and Hambrick (1989) argued that the public may create social pressures that may affect the determinants of executive compensations. Similarly, Weisbach (2007) argues that firms may cover-up executive compensation by letting it take on forms that are typically not discussed in the press, so as not to attract public attention. In the same vein, Bebchuk and Fried (2004) call public scrutiny as "outrage constraint", as they indicated that executives are cautious not to break this constraint as this may damage their reputation.

According to the above mentioned arguments, it is anticipated that executives would get less total compensation during the crisis periods including the GFC, while they will get more equity compensation during the same period. Moreover, we expect that CEO would try to reduce their ownership before crisis period to avoid large losses that would result from the sharp decline anticipated in stock prices during crisis time. Accordingly, the study would argue that they would own less shares during crisis period. Thus, the study posits the following three hypotheses: 
Hc3: The level of executive compensation decreased during the GFC

Hc4: Executives get more equity compensation during the GFC

Hc5: Executives shares ownership decreases during the GFC

\subsection{The Effect of Corporate Governance Mechanisms on Earnings Management and Executive Compensation during Financial Crisis}

There were extensive research on corporate governance over the last two decades. This research provided good understandings for the effects different effects of corporate governance on institutional environment. Nevertheless, many questions still unanswered and more research gaps still uncovered (Boubaker and Nguyen, 2017). One of these opened questions is what were the effects of corporate governance on reducing agency problems during financial crisis? In addition, if corporate governance system is working well during normal times, is this the case during crisis times?

Corporate governance mechanisms can play dual role in reducing agency problems and its effects (Shleifer and Vishny, 1997). On the one hand, they can mitigate opportunistic behaviour of management by reducing accounting manipulation. On the other hand, some corporate governance mechanisms might control executive compensation policies. The literature provides extensive evidence for the effect of corporate governance mechanisms such board independence and efforts, audit committee's independence and expertise, and external auditor's quality and independence on mitigating earnings management practices (e.g. Dechow et al., 1995; Beasley et al., 2000; Klein, 2002; Xie et al., 2003; Bédard et al., 2004; Piot and Janin, 2007; Srinidhi et al., 2007; Cornet et al., 2008; Jaggi et al. 2009; Sáenz González, 2014).

\section{Methodology}

The initial sample of this study includes an unbalanced panel of the non-financial companies listed on FTSE-350 index. The FTSE350 index has been selected because it includes, by capitalisation, the largest 350 companies which have their primary listings on the London Stock Exchange. Financial companies were excluded because these companies have different legal and regulatory reporting requirements. This resulted in the elimination of 100 
companies. Of the remaining 250 firms, 4 firms were excluded because their annual reports were not available. A further 31 firms were excluded either because the required variables for the calculation of the proxies for compensation and corporate governance were not available, or they belong to an industry with less than 8 firms (the calculation of DACs requires that there be at least 8 firms in the industry). The above processes left a final sample of 215 firms and 1675 firm-year observations as shown in Table 1 below.

Table 1: Sample Selection Procedure

\begin{tabular}{lc}
\hline \multicolumn{1}{c}{ Description } & $\begin{array}{c}\text { Number of } \\
\text { Companies }\end{array}$ \\
\hline Initial Sample (FTSE 350 Index) & 350 \\
Exclude: & \\
Financial Companies & 100 \\
Annual reports are not found & 4 \\
Compensation data are not found & 8 \\
Corporate governance data are not found & 7 \\
Firms with less than 4 year of data & 13 \\
Industry groups with less than 8 firms & 3 \\
Final Sample & 215 \\
Total Firm-Year Observations (2004-2011) & 1675 \\
\hline
\end{tabular}

The current paper uses a number of earnings management variables. These variables are the absolute, positive and negative values of current discretionary accruals. These variables were calculated using the performance adjusted model (Kothari et al., 2005), and the absolute, positive and negative values of total discretionary accruals, which were calculated using the modified Jones model (Dechow et al., 1995). With regard to executive compensation variables, the study employed a number of variables for both CEOs and CFOs. These variables are salary, bonus, total direct compensation, equity linked compensation, total compensation and ownership. Table 2 provides a description of the earnings management and executive compensation variables included in the current analysis. The aim of this paper is to examine the effect of the GFC on earnings management practices and the level and structure of executive compensation amongst UK listed companies. Accordingly, two independent 
sample T-test will be employed to achieve this aim. To perform the T-test, the sample periods were divided into two sub-periods: (i) financial crisis period (2007-2008) and non-crisis periods (20042006 \& 2009-2011). Furthermore, the study goes a step further and examined the effect of corporate governance quality on the effect of global financial crisis on earnings management and executive compensation. This will be done through subdividing our firms to good and poor corporate governance quality, and then we will examine the effect of global financial crisis on those two groups. To reduce the effect of extreme values all variables have been winsorized at $5 \%$ and $95 \%$ of its distribution.

Table 2: Description of the Earnings Management and Executive Compensation Variables

\begin{tabular}{|c|c|}
\hline Va & Description \\
\hline \multicolumn{2}{|c|}{ Panel A: Earnings Management Variables: } \\
\hline CDA_ABS & $\begin{array}{l}\text { Absolute values of current discretionary } \\
\text { accruals }\end{array}$ \\
\hline CDA_INC & $\begin{array}{l}\text { Positive values of current discretionary } \\
\text { accruals }\end{array}$ \\
\hline CDA_DEC & $\begin{array}{l}\text { Negative values of current discretionary } \\
\text { accruals }\end{array}$ \\
\hline TDA_ABS & $\begin{array}{l}\text { Absolute values of total discretionary } \\
\text { accruals }\end{array}$ \\
\hline TDA_INC & $\begin{array}{l}\text { Positive values of total discretionary } \\
\text { accruals }\end{array}$ \\
\hline TDA_DEC & $\begin{array}{l}\text { Negative values of total discretionary } \\
\text { accruals }\end{array}$ \\
\hline \multicolumn{2}{|c|}{ Panel B: Executive Compensation Variables: } \\
\hline Salary & Executive's base annual salary \\
\hline Bonus & Executive's annual cash bonus \\
\hline Total Direct & Sum of all cash based compensation \\
\hline Equity Linked & Sum of shares awarded, estimated value of \\
\hline Total & Total direct + total equity linke \\
\hline Ownership & Number of Shares owned by the executive \\
\hline
\end{tabular}

Note: This table provides a description of each of the earnings management and executive compensation variables included in the analysis. 


\section{The Results}

This section presents the results of data analysis. The study begins by presenting the descriptive statistics for earnings management and executive compensation variables, while the results of hypotheses testing will be highlighted thereafter.

\subsection{Descriptive Statistics}

Table 3 presents the descriptive statistics for earnings management measures which are the absolute and directional values of the current discretionary accruals derived from Kothari model. The reported figures are for $\mathbf{1 6 7 5}$ firm-year observations for the period 2004-2011. The mean and median for the absolute values of current discretionary accruals are 0.0465 and .0299 respectively. The minimum and maximum values are 0.0001 and 0.492 respectively. The results also indicate some little variation in the reported figures for the discretionary accruals, as can be seen from the standard deviation values in Table $3(0.052)$. The percentage of income increasing earnings management is $44.18 \%$ (740 out of 1675) firm-year observations. On the other side, $55.82 \%$ (935 out of 1675) of our firm-year observations show income decreasing earnings management. This means that income decreasing earnings management slightly outweigh income increasing in earnings management in the sample companies during the investigated period. The mean and median values for CDA_INC (proxy for income increasing earnings management) is 0.0443 and 0.0279 respectively, whereas the mean and median values of CDA_DEC (proxy for income decreasing earnings management) are $-\mathbf{0 . 0 4 8}$ and $\mathbf{- 0 . 0 3 0 8}$. 
Table 3: Descriptive Statistics of Earnings Management and Executive Compensation Variables

\begin{tabular}{|c|c|c|c|c|c|c|}
\hline Variables & Observations & Mean & Median & StDv & Min & Max \\
\hline \multicolumn{7}{|c|}{ Panel A: Discretionary Accrual Measures as a Proxy of Earnings Management } \\
\hline CDA_ABS & 1675 & 0.0465 & 0.0299 & $\mathbf{0 . 0 5 2 0}$ & 0.0001 & 0.492 \\
\hline CDA_INC & 740 & 0.0443 & 0.0279 & 0.049 & 0.0001 & 0.3004 \\
\hline CDA_DEC & 935 & -0.048 & -0.0308 & 0.054 & -0.492 & -0.0001 \\
\hline \multicolumn{7}{|c|}{ Panel B: Executive Compensation Variables } \\
\hline CEO_Salary & 1675 & $\mathbf{5 0 7 . 1 9}$ & 460 & 205.66 & 240 & 878 \\
\hline CEO_Bonus & 1675 & 368.44 & 293 & 307.44 & $\mathbf{0}$ & 958 \\
\hline CEO_Direct & 1675 & 1016.59 & 855.5 & 549.79 & 381 & 2096 \\
\hline CEO_Equity & 1675 & 1238.40 & 714 & 1213.10 & 174 & 3999 \\
\hline CEO_Total & 1675 & 2549.07 & 1685.5 & 2273.07 & 565 & 9206 \\
\hline CEO_Own & 1675 & 3719.74 & 1152 & 5264.86 & 101 & 16735 \\
\hline CFO_Salary & 1540 & 307.51 & 288 & 114.83 & 150 & 508 \\
\hline CFO_Bonus & 1540 & 199.46 & 165 & 155.82 & $\mathbf{0}$ & 491 \\
\hline CFO_Direct & 1540 & 579.55 & 518 & 276.07 & 240 & 1107 \\
\hline CFO_Equity & 1540 & 633.50 & 417 & 562.24 & 98 & 1865 \\
\hline CFO_Total & 1540 & 1322.44 & 972 & 988.35 & 336 & 4006 \\
\hline CFO_Own & 1540 & 655.80 & 285 & 781.15 & 24 & 2391 \\
\hline
\end{tabular}

Note: This table shows the number of observation, mean, median and standard deviation (StDv) for discretionary accrual measures as a proxy of earnings management and executive compensation variables. See Table 1 for variables definitions. Variables are presented in $£ 000$.

Table 3 also shows the descriptive statistics with regard to CEO and CFO compensation components during the investigated period. The mean (median) of annual total compensation of CEO is $£ 2.5$ ( $£ 1.685)$ millions. The mean (median) annual CEO's salary and cash bonus are $£ 507$ ( $£ 368$ ) thousands and $£ 460$ (£293) thousands, respectively. The mean (median) CEO's direct compensation are $£ 1016$ ( $£ 855$ ) thousands, whereas the CEO's mean (median) annual equity linked compensation are $£ 1425$ (£714) thousands respectively. On the other hand, the average CFO components are approximately half of CEO's values, as can be seen from Table 3. The mean (median) CFO's total annual compensation are $£ 1322$ ( $£ 972$ ) thousands. The mean (median) CFO's salary and bonus are $£ 307.5(282)$ thousands and $£ 199$ (£165) thousands respectively. The mean (median) CFO's direct and equity linked compensation are $£ 597.5$ ( $£ 518$ ) thousands and $£ 633.5$ (£417) thousands, respectively. 


\subsection{The Effect of Global Financial Crisis on Earnings Management Practices}

This section discusses the results of examining the effect of the GFC on the level and direction of earnings management. Table 4 shows the result of the t-test to examine if there are any significant differences between the level and direction of earnings management in the non-crisis and crisis periods. The findings reveal that firms did practice more earnings management during the crisis periods as can be seen from Table 4 . The difference is significant at the $99 \%$ and $95 \%$ levels for the absolute values of current and total discretionary accruals respectively (p-values 2.796 and $\mathbf{- 1 . 9 6 8 8}$ respectively). These results support hypothesis Hc1 that firms practiced more earnings management during the GFC.

Regarding the direction of earnings management, opposite to hypothesis Hc2, the results revealed that firms managed earnings downward during the crisis period. In this regard, the study did not find significant change of positive value of current discretionary accruals during financial crisis period, whereas positive values of total discretionary accruals is lower during crisis period, as can be seen from Table 4. On the other hand, the study reported a significant increase in the negative values of both current and total discretionary accruals. These findings support the argument that firms manage earnings downward during economic crisis periods. As mentioned before, firms may manage earnings downward to gain governmental aids or get some concessions from the lenders through reporting losses (Shleifer and Vishny, 1992; Asquith and Gertner, 1994; DeAngelo et al., 1994). These results are consistent with Jenkins et al. (2009) and Huijgen and Lubberink (2005) who indicated that during crisis periods firms tend to report more conservative earnings.

Table 4: Change in Earnings Management

\begin{tabular}{|c|c|c|c|c|c|}
\hline \multirow{2}{*}{ Variables } & \multicolumn{2}{|c|}{ Non-Crisis Period } & \multicolumn{2}{|c|}{ Crisis Period } & \multirow{2}{*}{$\begin{array}{c}\text { T-test } \\
\text { t-value }\end{array}$} \\
\hline & Mean & StDv & Mean & StDv & \\
\hline CDA_ABS & .0443 & 0512 & .0525 & .0538 & $-2.796 * * *$ \\
\hline TDA_ABS & .0646 & .0645 & .0717 & .0669 & $-1.9688^{* * *}$ \\
\hline CDA_INC & .0429 & .0490 & .0480 & .0484 & -1.2572 \\
\hline TDA_INC & .0626 & .0728 & .0494 & .0473 & $1.95015 *$ \\
\hline CDA_DEC & -.0455 & .0490 & -.0564 & .0484 & $2.6451 * * *$ \\
\hline TDA_DEC & -.0653 & .0529 & -.0820 & .0579 & $3.8757 * * *$ \\
\hline
\end{tabular}


Note: This table shows the mean, standard deviation (StDv) for the discretionary accrual measures as a proxy of earnings management in the non-crisis and crisis periods. It also provides the p-value for the $\mathbf{T}$-test. $\mathbf{A} *, * *, * * *$ indicate significance at the $10 \%, 5 \%$, and $1 \%$ levels respectively. See Table 1 for variables definitions.

\subsubsection{The Impact of Corporate Governance Quality on Earnings Management}

This section goes further to investigate the link between corporate governance practices of the sample companies and their earnings management during the investigated period. Instead of using individual corporate governance mechanisms as a proxy for corporate governance quality, the study use an overall index for corporate governance system. The index reflects the effect of a group of corporate governance variables rather than measuring the effect of each individual variable (Webb, 2006). The use of general index instead of individual corporate governance mechanisms has a twofold benefit. First, it gives more accurate measurement for the strength of corporate governance system instead of the individual mechanisms that may give contradicting effects. Second, it enables measuring the effect of corporate governance system on the equity incentives relationship in three ways, firstly by including this index as additional control variable similar to individual mechanisms, secondly by including a new variable that measures the interaction between equity incentives and corporate governance, and finally by dividing our sample into two groups according to corporate governance index. This separation will enable comparing the direction and significance of equity incentives-earnings management relationship with respect to companies with strong and weak corporate governance practices.

The Institutional Shareholder Services (ISS) issued new corporate governance indexes measuring the quality of corporate governance in the UK capital market. ISS is the world principal supplier of proxy voting and corporate governance services, with over 20 years of experience. ISS serves more than 1,600 institutional and corporate users worldwide with its main business - analysing proxies and issuing informed research and objective vote recommendations for more than 33,000 companies across 115 
markets worldwide. ISS' Corporate Governance Quotient (CGQ) ${ }^{1}$ was established to assist institutional investors in evaluating the quality of corporate boards, and the impact governance practices may have on portfolio performance. Many of the world's largest and most respected financial institutions have incorporated ISS' CGQ ratings into various aspects of their equity research and investment decision-making processes. According to ISS' indexes, the higher the value of the index, the higher is the quality of corporate governance.

Using corporate governance index, the sample companies was divided into two categories: (ii) good corporate governance quality companies and (ii) poor corporate governance quality companies. The main aim of this distinction between the two groups is to examine the effect of corporate governance quality on firms' behaviour regarding earnings management practices during the financial crisis period. Panels A and B of Table 5 shows that firms with good corporate governance system had higher levels of current discretionary accruals during crisis period compared to their counterparts with poor corporate governance systems. On the other hand, firms with good corporate governance system had less total accruals during financial crisis period as can be seen from Table 5 Panel $A$. In addition, with regard to the level of positive current or total discretionary accruals for companies with good or poor corporate governance systems, the results reveal no significant differences. Moreover, the results showed that firms that have better corporate governance system had more negative current discretionary accruals during financial crisis. Finally, the findings indicated that both firms with good or poor corporate governance system had higher levels of negative total discretionary accruals during financial crisis time; nevertheless, the difference is more significant in the case of poor corporate governance system. All in all, these results indicate that although corporate governance quality does affect earnings management practices during financial crisis period; however this effect is not consistent over all proxies of earnings management. It is more effective in affecting earnings management measured through total discretionary accruals than current discretionary accruals. Consistent with this result, Erkens et al. (2012) indicated that the

\footnotetext{
${ }^{1}$ CGQ is the industry's most comprehensive corporate governance database, scoring more than 8,000 companies worldwide, and representing more than $98 \%$ of the US equity market and all of the major global indices.
} 
effect of CG practices in reducing the consequences of future economic crises is still questionable.

Table 5: Earnings Management and Corporate Governance Systems

\begin{tabular}{|c|c|c|c|c|c|}
\hline \multirow[t]{2}{*}{ Variables } & \multicolumn{2}{|c|}{ Non-Crisis Period } & \multicolumn{2}{|c|}{$\begin{array}{c}\text { Financial Crisis } \\
\text { Period }\end{array}$} & \multirow{2}{*}{$\begin{array}{c}\text { T-test } \\
\text { t-value }\end{array}$} \\
\hline & Mean & StDv & Mean & StDv & \\
\hline \multicolumn{6}{|c|}{ Panel A: Firms with Good Corporate Governance Systems } \\
\hline CDA_ABS & .0424 & .0496 & .0500 & .0530 & $-2.1697 * *$ \\
\hline TDA_ABS & .0627 & .0650 & .0679 & .0666 & -1.1462 \\
\hline CDA_INC & .0423 & .0470 & .0458 & .0454 & -0.7429 \\
\hline TDA_INC & .0599 & .0732 & .0478 & .0460 & 1.4686 \\
\hline CDA_DEC & -.0424 & .0516 & -.0538 & .0591 & $2.2404 * *$ \\
\hline TDA_DEC & -.0638 & .0614 & -.0673 & .0646 & $2.5362 * *$ \\
\hline \multicolumn{6}{|c|}{ Panel B: Firms with Poor Corporate Governance Systems } \\
\hline CDA_ABS & .0481 & .0540 & .0574 & .0551 & $-1.7934 *$ \\
\hline TDA_ABS & .0679 & .0634 & .0789 & .0672 & $-1.8049 *$ \\
\hline CDA_INC & .0439 & .0526 & .0527 & .0543 & -1.1288 \\
\hline TDA_INC & .0676 & .0720 & .0636 & .0503 & 1.2792 \\
\hline CDA_DEC & -.0512 & .0549 & -.0608 & .0558 & 1.3821 \\
\hline TDA_DEC & -.0679 & 0599 & -.0901 & .0704 & $3.1186 * * *$ \\
\hline
\end{tabular}

Note: This table shows the mean, standard deviation (StDv) for the discretionary accrual measures as a proxy of earnings management in the non-crisis and crisis periods. It also provides the p-value for the T-test. $\mathbf{A} *, * *, * * *$ indicate significance at the $10 \%, 5 \%$, and $1 \%$ levels respectively. See Table 1 for variables definitions.

\subsection{The Effect of Global Financial Crisis on Executive Compensation}

This section of the paper discusses the reaction of the sample firms to the global financial crisis with respect to the level and structure of compensation provided to their CEO and CFO. The results show that the average CEO total compensation decreased

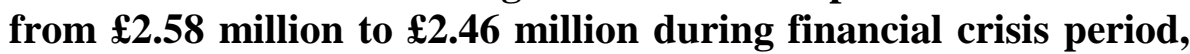
but the difference is not significant as can be seen from Table 6 . This result incompletely supports our hypothesis Hc3 that the level of executive pay declines during crisis time. Regarding the structure of CEO pay, the findings show that CEO got more salaries, bonuses and direct compensations in general, while they got less equity linked compensation during crisis period. These results do not support hypothesis $\mathrm{HC} 4$ that firms would prefer to offer more equity linked compensation during crisis time 
compared to cash and other direct compensation to avoid public anger. Moreover, the study finds that CEO' shares ownership increases during financial crisis period, implying that they could not anticipate the financial crisis. Accordingly, hypothesis HC5 that CEO's ownership would decline during financial crisis period, is rejected. This result is not consistent with the argument that CEOs could anticipate crisis and therefore had the ability to trade off their shares and this would decrease their ownership.

The results of CFO are similar to that of CEO except for shares ownership which, opposite to CEO, decreased during crisis period. A possible explanation of this result is that CEO is subject to more scrutiny from media and the public in general and they are exposed to more litigation risk. Therefore, they could not trade out their shares before crisis in contrast to other executives who may have less pressure from outside parties and would have more freedom to trade out their positions before crisis.

Table 6: Executive Compensation Level and Structure during the GFC

\begin{tabular}{|l|c|c|c|c|c|}
\hline \multirow{2}{*}{ Variables } & \multicolumn{2}{|c|}{ Non-Crisis Period } & \multicolumn{2}{c|}{ Crisis Period } & T-test \\
\cline { 2 - 6 } Mean & StDv & Mean & StDv & t-value \\
\hline CEO_SALARY & $\mathbf{5 0 8 . 4 5 1}$ & $\mathbf{2 2 8 . 7 8 0}$ & $\mathbf{5 2 0 . 6 2 3}$ & $\mathbf{2 2 7 . 2 0 4}$ & $\mathbf{- 0 . 9 4 1}$ \\
\hline CEO_DIRECT & $\mathbf{1 0 3 3 . 9 3 5}$ & $\mathbf{6 5 0 . 3 0 9}$ & $\mathbf{1 0 9 6 . 8 6 3}$ & $\mathbf{6 4 5 . 9 6 4}$ & $-\mathbf{- 1 . 7 1 2 ^ { * }}$ \\
\hline CEO_EQUITY & $\mathbf{1 4 7 6 . 2 9 6}$ & $\mathbf{1 7 5 3 . 8 7}$ & $\mathbf{1 2 8 6 . 4 7 9}$ & $\mathbf{1 6 3 7 . 8 0 8}$ & $\mathbf{1 . 8 2 2} *$ \\
\hline CEO_TOTAL & $\mathbf{2 5 8 1 . 8 8 4}$ & $\mathbf{2 2 9 6 . 5}$ & $\mathbf{2 4 5 9 . 4 0 9}$ & $\mathbf{2 2 0 8 . 3}$ & $\mathbf{0 . 8 9 2}$ \\
\hline CEO_OWN & $\mathbf{6 1 7 2 . 7 0 2}$ & $\mathbf{1 2 9 9 2 . 4}$ & $\mathbf{6 6 3 8 . 3 9 1}$ & $\mathbf{1 3 9 1 8 . 4 2}$ & $\mathbf{- 0 . 6 0 2}$ \\
\hline CFO_SALARY & $\mathbf{3 0 7 . 6 6 2}$ & $\mathbf{1 2 9 . 3 9 3}$ & $\mathbf{3 1 7 . 1 8 1 8}$ & $\mathbf{1 3 1 . 9 7 5}$ & $\mathbf{- 1 . 2 6 9}$ \\
\hline CFO_BONUS & $\mathbf{2 0 5 . 2 7 4}$ & $\mathbf{1 8 0 . 0 9 3}$ & $\mathbf{2 2 9 . 6 5 8}$ & $\mathbf{1 8 5 . 0 8 4 9}$ & $\mathbf{- 2 . 3 2 6 * *}$ \\
\hline CFO_DIRECT & $\mathbf{5 7 8 . 4 5 8}$ & $\mathbf{3 1 3 . 3 0 9}$ & $\mathbf{6 2 1 . 9 0 7}$ & $\mathbf{3 2 3 . 5 1 6 6}$ & $\mathbf{- 2 . 3 8 3 * *}$ \\
\hline CFO_EQUITY & $\mathbf{7 1 7 . 9 5 0}$ & $\mathbf{7 3 2 . 0 6 4}$ & $\mathbf{6 3 5 . 3 9 7}$ & $\mathbf{7 0 8 . 0 8 6}$ & $\mathbf{1 . 8 6 9 *}$ \\
\hline CFO_TOTAL & $\mathbf{1 3 3 2 . 6 6}$ & $\mathbf{9 9 0 . 5 1 6}$ & $\mathbf{1 2 9 4 . 3 0 7}$ & $\mathbf{9 8 3 . 1 6 3}$ & $\mathbf{0 . 6 3 7 4}$ \\
\hline CFO_OWN & $\mathbf{7 9 0 . 4 6 2}$ & $\mathbf{1 1 1 6 . 4 1}$ & $\mathbf{7 7 0 . 0 4 9}$ & $\mathbf{1 1 2 3 . 2 5 8}$ & $\mathbf{0 . 2 9 9 8}$ \\
\hline
\end{tabular}

Note: This table shows the mean, standard deviation (StDv) for different components of compensations provided to CEO and CFO in the non-crisis and crisis periods. It also provides the pvalue for the T-test. A *,**,*** indicate significance at the $10 \%$, $5 \%$, and $1 \%$ levels respectively. See Table 1 for variables definitions. 


\subsection{The Impact of Corporate Governance Quality on Executive Compensation}

This section shed light on the effect of corporate governance quality on executives' compensation level and structure during financial crisis. As mentioned above, the study employed the corporate governance index, consequently the sample companies was divided into two categories: (ii) good corporate governance quality companies and (ii) poor corporate governance quality companies. The results, which are presented in Table 7, indicate that corporate governance quality did not have a significant impact on the level and structure of executive compensation during financial crisis as very close results were reported with respect to good and poor corporate governance samples. In addition, these results are consistent with those obtained from the whole sample. Generally speaking, these results combined with the results we obtained regarding the effect of corporate governance quality on the change on earnings management practices during financial crisis period raise a question mark about the effectiveness of current corporate governance systems.

Table 7: Executive Compensation and Corporate Governance System

\begin{tabular}{|c|c|c|c|c|c|}
\hline \multirow[t]{2}{*}{ Variables } & \multicolumn{2}{|c|}{ Non-Crisis Period } & \multicolumn{2}{|c|}{ Crisis Period } & \multirow{2}{*}{$\begin{array}{l}\text { T-test } \\
\text { t-value }\end{array}$} \\
\hline & Mean & StDv & Mean & StDv & \\
\hline \multicolumn{6}{|c|}{ Panel A: Firms with Good Corporate Governance Systems } \\
\hline CEO_SALARY & 500.967 & 208.585 & 505.738 & 206.770 & -0.328 \\
\hline CEO_BONUS & 357.701 & 344.8426 & 392.134 & 334.996 & -1.433 \\
\hline CEO_DIRECT & 988.819 & 591.616 & 1036.81 & 582.0412 & -1.167 \\
\hline CEO_EQUITY & 1337.471 & 1604.146 & 1174.024 & $\mathbf{1 5 2 8 . 3 5 7}$ & 1.389 \\
\hline CEO_TOTAL & 2388.456 & 2108.452 & 2281.484 & 2025.676 & 0.690 \\
\hline CEO_OWN & 6056.109 & 12830.64 & 5830.438 & 12443.31 & 0.246 \\
\hline CFO_SALARY & 300.168 & 119.479 & 308.178 & 122.376 & -0.936 \\
\hline CFO_BONUS & 190.374 & 169.895 & 214.418 & 176.006 & $-1.967 *$ \\
\hline CFO_DIRECT & 556.871 & 291.057 & 595.848 & 297.595 & $-1.871 *$ \\
\hline CFO_EQUITY & 661.933 & 678.798 & $\mathbf{5 8 0 . 4 5 2}$ & 651.429 & 1.612 \\
\hline CFO_TOTAL & 1245.573 & 909.768 & 1213.17 & 908.8508 & 0.473 \\
\hline CFO_OWN & 760.896 & 1073.304 & 700.125 & 0.7587 & 0.759 \\
\hline \multicolumn{6}{|c|}{ Panel B: Firms with Poor Corporate Governance Systems } \\
\hline CEO_SALARY & 522.296 & 261.772 & 549.664 & 260.886 & -1.081 \\
\hline CEO_BONUS & 446.939 & 420.338 & 486.028 & 421.365 & -0.958 \\
\hline
\end{tabular}




\begin{tabular}{|c|c|c|c|c|c|}
\hline CEO_DIRECT & 1117.382 & 740.361 & 1214.028 & 743.624 & -1.346 \\
\hline CEO_EQUITY & 1744.003 & 1986.612 & 1507.817 & 1820.485 & 1.169 \\
\hline CEO_TOTAL & 2954.883 & 2583.938 & 2809.611 & 2501.412 & 0.546 \\
\hline CEO_OWN & 6390.122 & 13302.64 & 8183.007 & 16312.61 & -1.274 \\
\hline CFO_SALARY & 321.409 & 144.993 & 334.732 & 147.823 & -0.928 \\
\hline CFO_BONUS & 232.95 & 194. & 259.254 & 198.894 & -1.360 \\
\hline CFO_DIRECT & 618.062 & $\mathbf{3 4 7 . 3 8 4}$ & 672.703 & 364.678 & -1.576 \\
\hline CFO_EQUITY & 822.683 & 813.173 & 739.661 & 797.086 & 0.99 \\
\hline CFO_TOTAL & 1495.487 & 1109.221 & 1448.276 & 1097.999 & 0.412 \\
\hline CFO_OWN & 844.842 & 1191.255 & 904.864 & 1258.23 & -0.479 \\
\hline
\end{tabular}

Note: This table shows the mean, standard deviation (StDv) for different components of compensations provided to CEO and CFO for companies with good and poor governance systems in the non-crisis and crisis periods. It also provides the $\mathbf{p}$-value for the $\mathbf{T}$ test. A $*, * *, * * *$ indicate significance at the $10 \%, 5 \%$, and $1 \%$ levels respectively. See Table 1 for variables definitions.

\section{Robustness Check}

As mentioned above, although the study winsorized most of the variables to exclude the effect of extreme values, nevertheless, this procedure does not guarantee the normality the variables included in the analysis as an important condition for using parametric tests such as the t-test. To check the probability of the effect of possible non-normality on our results, the study repeats the test using Mann-Whitney test. Mann-Whitney is a nonparametric test that is commonly used when you do not assume that the dependent variable is a normally distributed interval variable. In addition to presenting $Z$-values and $P$-values, the study presents the medians values of all variables during crisis and non-crisis periods.

The results of the Mann-Whitney test regarding the effect of global financial crisis on earnings management practices are presented in Table 8. The results are consistent with those obtained from the T-test shown in Table 4. The differences are only on the significance levels. CDA_ABS is significant at $1 \%$ compared to $5 \%$ level of significance in the $T$-test as can be seen in Table 4. By contrast, the significance of TDA_ABS decreased from $5 \%$ to $10 \%$. Furthermore, TDA_INC does not show any 
level of significance, whereas it was significant at $10 \%$ in the $T$ test. Finally, the significance of CDA_DEC declined from 1\% to $5 \%$.

Table 8: Change in Earnings Management

\begin{tabular}{|l|c|c|c|}
\hline \multirow{2}{*}{ Variables } & Non-Crisis Period & Crisis Period & \multirow{2}{*}{$\begin{array}{c}\text { Mann-Whitney } \\
\text { P-values }\end{array}$} \\
\cline { 2 - 3 } & \multicolumn{2}{|c|}{ Median } & $-3.453^{*} * *$ \\
\hline CDA_ABS & .0276 & .03595 & $\mathbf{- 1 . 7 2 2} *$ \\
\hline TDA_ABS & .0471 & .05175 & $-\mathbf{0 . 1 0 3}$ \\
\hline CDA_INC & .0257 & .0341 & $\mathbf{0 . 9 5 2}$ \\
\hline TDA_INC & .0379 & .0409 & $\mathbf{2 . 4 3 6} * *$ \\
\hline CDA_DEC & $\mathbf{- . 0 2 8 8}$ & $\mathbf{- . 0 3 7 6}$ & $\mathbf{3 . 1 1 8} * * *$ \\
\hline TDA_DEC & $\mathbf{- . 0 4 9 8 7}$ & $\mathbf{- . 0 6 0 8}$ & \\
\hline
\end{tabular}

Note: This table shows the median for the discretionary accrual measures as a proxy of earnings management in the non-crisis and crisis periods. It also provides the p-value for the Mann-Whitney test. A *, **, *** indicate significance at the $10 \%, 5 \%$, and $1 \%$ levels respectively. See Table 1 for variables definitions.

Table 9 presents the results of the Mann-Whitney test for the change in executive compensation variables during the investigated periods. The results are relatively similar with those obtained from T-test shown in Table 6. Generally, the level of significance is higher for some variables. The significance of differences is evident with respect to CEO_BONUS, CEO_DIRECT, CEO_EQUITY, CFO_BONUS, and CFO_EQUITY are higher under the Mann-Whitney test compared to the T-test. On the other side, contrary to T-test results, the ownership of CEO decreased during financial crisis period.

Table 9: Change in Executive Compensation

\begin{tabular}{|c|c|c|c|}
\hline \multirow{2}{*}{ Variables } & Non-Crisis Period & Crisis Period & \multirow{2}{*}{$\begin{array}{c}\text { Mann-Whitney } \\
\text { P-values }\end{array}$} \\
\hline & \multicolumn{2}{|c|}{ Median } & \\
\hline CEO_SALARY & 455 & 475 & -1.049 \\
\hline CEO_BONUS & 283 & 330 & $-2.512 * *$ \\
\hline CEO_DIRECT & 840 & 911.5 & $-2.418 * *$ \\
\hline CEO_EQUITY & 753 & 604 & $2.889 * * *$ \\
\hline CEO_TOTAL & $\mathbf{1 7 1 7 . 5}$ & 1592 & 0.867 \\
\hline CEO_OWN & 1183 & 1065.5 & 0.219 \\
\hline CFO_SALARY & 284 & 295 & -1.238 \\
\hline CFO_BONUS & 158 & 182 & $-2.620 * * *$ \\
\hline CFO_DIRECT & 505 & 544 & $-2.571 * *$ \\
\hline CFO_EQUITY & 437 & 365 & 2.411** \\
\hline CFO_TOTAL & 991 & 921 & 0.709 \\
\hline CFO_OWN & 273 & 305 & 0.155 \\
\hline
\end{tabular}


Note: This table shows the median for different components of compensations provided to $\mathrm{CEO}$ and $\mathrm{CFO}$ in the non-crisis and crisis periods. It also provides the p-value for the Mann-Whitney test. $\mathrm{A} *, * *, * * *$ indicate significance at the $10 \%, 5 \%$, and $1 \%$ levels respectively. See Table 1 for variables definitions.

\section{Summary and Conclusion}

The main research question of the current paper have been motivated by the global financial crisis that hit almost the whole globe in 2007-2008. This paper examined the effect of the global financial crisis on the level as well as the direction of earnings management during crisis period. In addition, it examined the effect of this crisis on the level and structure of executive compensation during the same period.

Regarding the effect of global financial crisis on earnings management practices, the study finds that firms engaged in higher levels of earnings management. In addition, the results show that firms manage earnings downward during financial crisis period. These results are consistent with the argument that firms may have recourse to income decreasing earnings management during crisis periods to gain governmental aid or to relax debt covenant or lower interest rates.

With regard to the effect of global financial crisis on executive compensation, the findings show that firms offer less total compensation levels during financial crisis. Regarding the structure of compensation, it was found that firms offer higher salaries, bonus, and direct compensation in general, whereas they offered less equity linked compensation during crisis period. Moreover, CEO's ownership increased during crisis period, implying that CEOs could not anticipate the financial crisis as they would sell much of their shares to avoid big losses resulting from the anticipated sharp decline in stock prices during this period. In addition, the study found that quality of corporate governance system does not have significant effect on earnings management practices or on the level and structure of executive compensation during financial crisis period. With respect to future research, the present study provide a springboard for future research in this area. The first expansion could be a cross-country comparative analysis of the impact of GFC on earnings management and executive compensations. In terms of widening the scope of the work in the area, a second expansion might also examine the value relevance of accounting numbers during crisis periods. 


\section{References}

Ahmad-Zaluki, N. A., Campbell, K. \& Goodacre, A. (2011) Earning Management in Malasian IPOs: The East Asian Crisis, Ownership Control and Post-IPO Performance. The International Journal of Accounting, Vol. 46, pp. 111-137.

Asquith, P. \& Gertner, R. (1994) Anatomy of Financial Distress. An Examination of Junk-Bond Issuers. Quarterly Journal of Economics, Vol. 109, No. 3, pp. 625-658.

Arthur, N., Tang, Q. and Lin, Z. (2015) Corporate accruals quality during the 2008-2010 Global Financial Crisis, Journal of International Accounting, Auditing and Taxation, Vol. 25, p. 1-25.

Beasley, M. S., Carcello, J. V., Hermanson, D. R. \& Lapides, P. D. (2000). Fraudulent Financial Reporting: Consideration of Industry Traits and Corporate Governance Mechanisms. Accounting Horizons, Vol.14, pp.441-454.

Bebchuk, L. A. \& Fried, J. M. (2004) Pay without Performance: The Unfulfilled Promise of Executive Compensation. Boston, Harvard University Press.

Bédard, J., Chtourou, S. M. \& Courteau, L. (2004). The Effect of Audit Committee Expertise, Independence, and Activity on Aggressive Earnings Management. Auditing, Vol.23, pp.330 .

Bepari, M.K., Rahman, S.F. and Mollik, A. (2013) Value relevance of earnings and cash flows during the global financial crisis, Review of Accounting and Finance, Vol. 12, No. 3, pp.226-251.

Boubaker, S. and Nguyen, D.K. (2017), "Governance Issues in Business and Finance in the Wake of the Global Financial Crisis", Journal of Management \& Governance, pp. 1-5. 
Charitou, A., Lambertides, N. \& Trigeorgis, L. (2007) Earnings Behaviour of Financially Distressed Firms: The Role of Institutional Ownership. Abacus, Vol. 43, pp. 271-296.

Chia, Y. M., Lapsley, I. \& Lee, H-W. (2007) Choice of Auditors and Earnings Management during the Asian Financial Crisis. Managerial Auditing Journal, Vol. 22, No. 2, pp. 177-196.

Cornett, M. M., Marcus, A. J. \& Tehranian, H. (2008). Corporate Governance and Pay-for-Performance: The Impact of Earnings Management. Journal of Financial Economics, Vol.87, pp.357-373.

DeAngelo, H., DeAngelo, L. \& Skinner, D. (1994) Accounting Choice in Troubled Companies. Journal of Accounting \& Economics, Vol. 17, No. 1-2, pp. 113-143.

Dechow, P. M., Sloan, R. G. \& Sweeney, A. P. (1995) Detecting Earning Management. The Accounting Review, Vol. 70, No. 2, pp. 193-225.

Defond, M. L. \& Francis, J. R. (2005) Audit Research after Sarbanes-Oxley. Auditing: A Journal of Practice \& Theory, Vol. 24, No. S-1, pp. 5-30.

Defond, M. L. \& Jiambalvo, J. (1993) Factors Related to AuditorClient Disagreements over Income-Increasing Accounting Methods. Contemporary Accounting Research, Vol. 9, No. 2, pp. 415-431.

Defond, M. L. \& Jiambalvo, J. (1994) Debt Covenant Violation and Manipulation of Accruals. Journal of Accounting \& Economics, Vol. 17, No. 1-2, pp. 145-176.

Defond, M. L. \& Park, C. W. (1997) Smoothing Income in Anticipation of Future Earnings. Journal of Accounting \& Economics, Vol. 23, No. 2, pp. 115-139.

Defond, M. L. \& Park, C. W. (2001) The Reversal of Abnormal Accruals and the Market Valuation of Earnings Surprises. The Accounting Review, Vol. 76, No. 3, pp. 375-404. 
Denis, D. K. \& McConnell, J. J. (2003) International Corporate Governance. Journal of Financial \& Quantitative Analysis, 38, 1-36.

Dichev, L. D. \& Skinner, D. J. (2001) Large-Sample Evidence on the Debt Covenant Hypothesis. Journal of Accounting Research, Vol. 40, No. 4, pp. 1091-1123.

Erkens, D., Hung, M \& Matos, P. (2012) Corporate governance in the 2007-2008 financial crisis: Evidence from financial institutions worldwide. Journal of Finance, Vol. 18, No. 2, pp. 389-411.

Fahlenbrach, R. \& Stulz, R. M. (2001) Bank CEO Incentives and the Credit Crisis. Journal of Financial Economics, Vol. 99, No. 1, pp. 11-26.

Falgi, K. I. (2009) Corporate Governance in Saudi Arabia: A Stakeholder Perspective. Un-published PhD Thesis, University of Dundee, Dundee, UK.

Filip, A. and Raffournier, B. (2014),"Financial Crisis and earnings management: The European evidence", The International Journal of Accounting, vol. 49, No. 4, pp. 455-478.

Finkelstein, S. \& Hambrick, D. C. (1989) Chief Executive Compensation: A Study of the Intersection of Market and Political Processes. Strategic Management Journal, Vol. 10, No. 2, pp. 121-134.

Healy, P. M. \& Wahlen, J. M. 1999. A Review of the Earnings Management Literature and its Implications for Standard Setting. Accounting Horizons, 13, 365-383.

Huijgen, C. \& Lubberink, M. (2005) Earnings Conservatism, Litigation and Contracting: The Case of Cross-Listed Firms. Journal of Business Finance \& Accounting, Vol. 32, No. 7-8, pp. 1275-1309.

Jaggi, B., Leung, S. \& Gul, F. (2009) Family Control, board Independence and Earnings Management: Evidence Based on Hong Kong Firms. Journal of Accounting and Public Policy, Vol. 28, No. 4, pp. 281-300. 
Jenkins, D. S., Kane, G. D. \& Velury, U. (2009) Earnings Conservatism and Value Relevance across the Business Cycle. Earnings Management: Evidence Based on Hong Kong Firms. Journal of Business Finance \& Accounting, Vol. 36, No. 9-10, pp. 1041-1058.

Jensen, M. C. \& Meckling, W. H. (1976) Theory of the Firm: Managerial Behaviour, Agency Costs and Ownership Structure. Journal of Financial Economics, Vol. 3, pp. 305360 .

Kane, G.D., Leece, R.D., Richardson, F.M. and Velury, U. (2015) The Impact of Recession on the Value-relevance of Accounting Information, Australian Accounting Review, Vol. 25, No. 2, pp. 185-191.

Klein, A. (2002). Audit Committee, Board of Director Characteristics, and Earnings Management. Journal of Accounting \& Economics, Vol.33, pp.375-400.

Murphy, K. J. (1985) Corporate Performance and Managerial Remuneration: An Empirical Analysis. Journal of Accounting \& Economics, Vol. 7, No. 1-3, pp. 11-42.

Piot, C. \& Janin, R. (2007). External Auditors, Audit Committees and Earnings Management in France. European Accounting Review, Vol.16, pp. 429-454.

Sáenz González, J. \& García-Meca, E. (2014), "Does Corporate Governance Influence Earnings Management in Latin American Markets?", Journal of Business Ethics, Vol. 121, No. 3, pp. 419-440.

Saleh, N. M. \& Ahmed, K. (2005) Earnings Management of Distressed Firms during Debt Renegotiation. Accounting and Business Research, Vol. 35, No. 1, pp. 69-86.

Shleifer, A. \& Vishny, R. W. (1992) Liquidation Values and Debt Capacity: A Market Equilibrium Approach. Journal of Finance, Vol. 47, No. 4, pp. 1343-1366.

Shleifer, A. \& Vishny, R. W. (1997) A Survey of Corporate Governance. Journal of Finance, Vol. 52, No. 2, pp. 737-783. 
Sincerre, B. P., Sampaio, J. O., Famá, R., \& dos Santos, J. O. (2016). Debt issues and earnings management. Revista Contabilidade \& Finanças, 27(72), pp. 291-305.

Srinidhi, B.N. \& Gul, F.A. (2007), "The Differential Effects of Auditors' Nonaudit and Audit Fees on Accrual Quality", Contemporary Accounting Research, vol. 24, no. 2, pp. 595629.

Strobl, G. (2013), "Earnings manipulation and the cost of capital", Journal of Accounting Research, Vol. 51, No. 2, pp. 449-473.

Sweeney, A. P. (1994) Debt-Covenant Violations and Managers' Accounting Responses. Journal of Accounting \& Economics, Vol. 17, No. 3, pp. 281-308.

Temin, P. (2010), "The Great Recession \& the Great Depression", Daedalus, vol. 139, no. 4, pp. 115-124.

Turner, A. (2009) A Regulatory Response to the Global Banking Crisis. March (Financial Service Authority).

Weisbach, M. S. (2007) Optimal Executive Compensation versus Managerial Power: A Review of Lucian Bebchuk and Jess Fried's Pay without Performance: The Unfulfilled Promise of Executive Compensation. Journal of Economic Literature, Vol. 45, No. 2, pp. 419-428.

Xie, B., Vidson Iii, W. N. \& Dadalt, P. J. (2003). Earnings Management and Corporate Governance: the Role of the Board and the Audit Committee. Journal of Corporate Finance, Vol.9, pp 295-316 
